\title{
New Periodicals of 1965-Part II
}

I

T MUST BE REMEMBERED by anyone who happens to consult this listing that the publications noted are not necessarily the best or the only new periodicals in a particular field. Those which have been mentioned have been chosen because they would seem to have some special value for libraries or cover material which is currently of great interest. A few, also, have been included because they are somewhat unusual (in format, in subject matter, or in the manner of their distribution) and their particular qualities might be overlooked in the rush to keep up with the flood of more ordinary journals.

Titles marked with an asterisk in the alphabetical section at the end of this listing are scholarly, scientific, or technical publications which have not been annotated in any way as the nature of their contents would appear to be obvious.

Abstracts, Bibliographies, Indexes. In this day of multitudinous publications almost any reliable aids which may be of help to librarians in book selection are invaluable. Sci-Tech Book Profiles and Medical Book Profiles are new monthlies which will reproduce (in reduced size) the title pages, tables of contents, names of contributors, prefaces and indexes of graduate or professional level books in their respective fields. The items selected for such treatment will be those in current issues of the American Book Publishing Record, and it is suggested that the Profiles, aside from their value as selection aids, may be used to decide whether a book which is not immediately available (out, missing, not purchased by the library) does indeed contain the information needed. One can predict excellent quality and a useful life for the Profiles when one sees R. R. Bowker Co. in the imprint. Another selection aid, also in the field of science, is Science Books, issued in the Miscellaneous Publications Series of the American Association for the Advancement of Science. Short reviews (three or four lines each) covering about two hundred books were included in the first issue. Each review is marked with symbols to show that the book is "not recommended," is "very simple elementary," is "professional," etc. Science Books would appear to be intended primarily for the use of the school librarian.

The currently available published proceedings of national and international conferences, meetings, symposia, and congresses in all areas of science and technology are listed in Directory of Published Proceedings. The meetings are arranged chronologically and indexed by city and by subject. Prices, current or estimated, are included.

East European Science Abstracts publishes five to seven line abstracts of East German, Polish, and Czech patents dealing with applied chemistry and technology, and other fields where chemicals are used. Journals from those countries are abstracted selectively and coverage is extended to certain Russian journals which are not known to be translated cover to cover.

Although it will include information on other minority groups, The Negro in Print is primarily an annotated listing of current American and foreign publications on the Negro. Adult and juvenile works as well as fiction and nonfiction will be noted and there will be announcements of forthcoming publications as well.

In English, but including the original German titles, is Mundus, a "quarterly review of German research contributions on Asia, Africa, and Latin America-arts and science." The review seems to be carefully done and should be of great value to librarians as each issue is divided into two parts (arts and economics; science and geography) each of which includes book notes and abstracts plus a selected bibliography of new books and articles.

Areas, Peoples. The Hellenic American National Picture Magazine introduces people of a common heritage. The first issue has articles on singer George Maharis and 
Detroit Lions' lineman Alex Karras as well as sections of news from Greece and from Greek communities in the United States. Another reminder that America is composed of people from many places is African Forum issued by the American Society of African Culture. The society is composed of some four hundred Americans of African descent who are teachers, scholars, and artists and its purpose has "been to bring to the American Negro, in particular, an understanding of the continuing value of our gifts and a pride in our origins so that we may join other Americans who feel secure in the traditions of their past and their contribution to America." The new quarterly will include articles on contemporary African society and cultural development as well as on the problems and contributions of American Negroes. There will also be a section concerned with national minorities and their problems of adjustment. The first issue of the Forum offers material by wellknown persons such as Jomo Kenyatta, Alex Quaison-Sackey, and James Farmer.

American libraries concerned with area studies may be interested in American Studies issued by the American Studies Association of the Philippines, a counterpart group to the American Studies Association in the United States. Despite its title the review will operate in an area of Philippine studies, that is, the investigation of problems bearing on the influence of American culture on the Philippines. The first issue has an interesting discussion of "Manuel L. Quezon and the American Presidents" and a Carlos Romulo contribution "American Literature and the Modern Sensibility."

Organ of the Center for Latin American Studies of the City College of the City University of New York, Centro will include a variety of articles, poems, and stories in English or in Spanish. Somewhat more scholarly, perhaps, is Latin American Research Review which is "devoted to systematic reviewing of current studies of Latin America." The Review is issued by the Latin American Research Review Board composed of representatives of each institution (ranging alphabetically from the University of Arizona to the University of Wisconsin) which has pledged financial support to the extent of $\$ 1,000$ annually to subsidize the Review for the first two years of its publication. The first issue contains topical reviews of "Social Stratification Research in Latin America" and "Urbanization in Latin America" as well as information on conferences, libraries, and new publications. There is also a special section listing research projects being undertaken in various institutions in this country. Future issues will also include research by Latin American institutions.

ThE ARTs. Syn, covering international contributions to the new art, takes its name from the Greek word meaning "together." Its articles, which have the same text in English and German, are designed to "open possibilities of an integral art beyond the hard-and-fast definitions of formalism (concrete art, optical art, hard-edge painting) or informalism (expressionism, tachism, action-painting) on the basis of pure painterly principles." As might be expected, there are many illustrations, some in color.

The rather slight Film Heritage is "not affiliated with any university" although it is published at the University of Dayton. Its first issue includes short pieces on "David Wark Griffith in Retrospect, 1965" and "Luis Alcoriza and the Films of Luis Bunuel." It has, also, a number of interesting black and white pictures. Theatre Design \& Technology concerns itself with the architectural aspects of dramatic presentations. It is the official publication of the U.S. Institute of Theatre Technology which wants to "bring about greater understanding between those who work in theaters and those who build them." The well-illustrated journal has articles about, and listings of, new theaters. It also includes current numbers of "Recent Publications on Theatre Architecture," a bibliography begun in 1960 and published separately through no. 12 .

The first issue of Lugano Review discusses Melville and philosophy and presents drawings (five by Thomas Merton) and paintings. The Review, well-printed in black and white with large type and clean, attractive pages, will devote itself to the whole field of the arts.

Business, Economics. Superseding the same publisher's Japan Trade Monthly, the new Industrial Japan explores economy and trade, devoting its first issue to advertising and marketing in Japan. The first issue has a most unusual three dimensional cover but, as one might expect, has many advertisements throughout. The April issue of each 
year is to be a special economic yearbook type of publication. Although the title African Commerce implies coverage of the whole continent, the first issue of the monthly review seems to concentrate on Uganda. The articles are the short summary type and touch on various aspects of African financial, commercial, and industrial progress.

Articles in Journal of Purchasing "may present concepts from business, statistics, economics, engineering, behavioral science, or any discipline which contributes to the advancement of knowledge in business or governmental purchasing, material management, or related areas . . . [ and $_{\mathrm{J}}$ may discuss theories, principles or philosophies." Business Economics represents a consolidation of some of the former publications of the National Association of Business Economists. Issues will have, in addition to regular articles, a special section devoted to a placement service.

Pergamon Press publishes Columbia Journal of World Business for the graduate school of business of Columbia University. The Journal seems to be of high quality and the articles included are written by men of stature in their fields. Even one who knows nothing of business, however, can appreciate the last article in the first issue "Pray Don't Call it English" (which has, among other gems: "The typical executive memo or report, generously larded with murky, flabby and pretentious phrases, seems almost to defy description. Call it cant, call it 'Businessese' but don't call it English").

Education. Designed to be torn apart for use in teaching safety, School Safety includes pages for bulletin boards, songs, stories, and other such materials. It would appear to be aimed at the elementary school teacher for in addition to teaching aids it has information on matters such as the dangers of contact lenses on the playground and ways of protecting the health of teachers.

Superseding Southern School News (published for eleven years) Southern Education Report will focus on programs to expand educational opportunities for the socially and economically handicapped in the southern and border states. It will, however, extend coverage to any promising concepts in education anywhere in the nation.
As did its predecessor, the Report will present an account of major events and trends in the area of the desegregation of education. The first issue includes discussions of current investigations such as the "North Carolina Advancement School" and "Early School Admission Project."

General. Primarily with colored illustrations, Voyageur explores wildlife, scenery, and historical events in a particular part of the country. Texts are short but the topics are of great interest. The first issue has "Where Time Stands Still," "Destiny of the Voyageurs," and "The Fascinating North Country Around Lake Superior."

Lithopinion is unusual in many ways. It is a quarterly published by Local One of the Amalgamated Lithographers of America and is distributed without cost to the Local's membership plus editors and other "leaders of opinion" (librarians included). The publishers say "there is not another magazine quite like this ... a general magazine on as high a level as any in the country, written by professionals, and offered to the community of free minds as a contribution by a labor union." The well written, beautifully illustrated first issue includes provocative articles on "Getting to Know Each Other" (labor and government), "Bread is Not Enough" (a writer behind the Iron Curtain), and "Labor's Non-Image on Television" (doctors, lawyers, etc. but few laboring men on TV). The many examples of the finest of the lithographic art, much of it in color, that are included appear because "this is not discussion that comes out of the woodwork, that has no mother or father or past or future. This is political and economic discussion that comes out of our particular view of the world as artist-craftsmen."

INTERNATIONAL AFFaIRs. Vista, pocket size and with capsule articles and features on people and events in the world of the $\mathrm{UN}$ and international affairs, is published by the United Nations Association of America (formerly the American Association for the United Nations) to replace its earlier UNA News.

Language, Literature. Although there are many journals in the field, few attempt, say the publishers (St. Andrews University, St. Andrews, Scotland) of Forum for Modern Language Studies, as extensive a cover- 
age. The Forum's scope will be the principal languages and literatures of Europe and America during the past millennium in the hope that a process of cross fertilization between different areas of study in the whole field can be encouraged. The contributors are asked to consider whether their work is likely to illumine, however obliquely, more than one small private corner. Other journals provide short reviews so Forum limits its reviews to a few substantial ones in which the authors concentrate on matters of substance and principle so the critique will itself contribute to the subject covered by the book. Half issues will be devoted, at frequent intervals, to papers on a single chosen subject or author. The second issue, for example, will have a number of papers on Dante and the fourth, on Corneille.

Northwest Folklore supersedes Oregon Folklore Bulletin and is particularly interested in publishing the "raw materials of folklore, that is, the actual collected superstitions, tales, songs, etc. of oral tradition." From time to time, as they have in the first issue, the publishers will present short investigative or critical articles on the folklore of the Northwest.

LAw. California Western Law Review is issued by the school of law of California Western University in San Diego. It is one of the latest in the long and often distinguished list of similar law school publications. Articles in the Review are not written by the students of the school but are edited by them under faculty supervision. In contrast, the faculty of the Louis Arthur Grimes School of Law of the University of Liberia in Monrovia issues Liberian Law Journal.

Articles in Lawyer's Medical Journal are written by doctors in fairly simple terminology. Each includes a short bibliography and tries to reduce "a complex medical problem to understandable terms, readily grasped by the trial attorney" in order to "provide workable techniques for evaluation of traumatic injuries" and to help to "bridge the widening gap between theory and practice in this growing field."

Polmtics, Government. Although the Office of the Federal Register of the General Services Administration now publishes similar material in annual volumes called
Public Papers of the Presidents it will attempt to supply current information through its Weekly Compilation of Presidential Documents. The Weekly will be issued every Monday and include whatever material has been released by the White House up to the previous Friday at 5 P.M. Coverage will include transcripts of the President's news conferences, messages to Congress, public speeches and statements. In addition there will be an index of contents, cumulative index, and list of laws approved by the President and nominations submitted by him to the Senate as well as a checklist of White House releases.

Asian Outlook has taken over the subscription list of Free China \& Asia published since October 1954 by the Asian Peoples Anti-Communist League of the Republic of China. The new publication is similar to the old in that much of its information is rather general in nature and many items are quoted (with appropriate comments) from Communist Chinese publications. Articles are very short and, of course, anti-Communist in nature. Two in the first issue are "Medical Training in Mainland China" and "An Indian View of the 'Second Bandung." "

Recreation. Devoted to the "fun" side of flying, Private Pilot will cover the national and international scene with concentration on the light plane picture. The publication is popularly written rather than technical in nature and seems, judging by the first issue, to put emphasis on first-hand accounts of experiences such as landing on a freeway in California or hunting coyotes from a plane.

RELIGION. Within the scope of Religious Studies will be, also, the psychology and sociology of religion as they bear on major religions and major religious questions. The Cambridge University Press publication will have, in addition to articles, extended book discussions, surveys of recent literature, and book notes.

ScIENCE. In October 1866, George Peabody gave Yale University a gift of $\$ 150,000$ for "the foundation and maintenance of a museum of natural history." Discovery, issued as a journal to inform and interest the Peabody Museum Associates, is one of the recent outgrowths of that original gift. Rather than following the form of a 
report, Discovery will discuss the museum's activities by means of articles on its collections and how material for them was gathered throughout the world. The first issue has many black and white illustrations and articles such as "Sea Bird Studies on Christmas Island," "Yale in Kenya," and "The Archaeological Expedition to Egyptian Nubia."

Replacing Arid Zone Newsletter (last issued December 1964) Nature and Resources will cover all the different aspects of UNESCO's Natural Resources Research Division investigations. Fields included are hydrology, geology, soil sciences, ecology, and the conservation of nature. The quarterly is subtitled "bulletin of the International Hydrological Decade" (the decade is 1965-1974).

Inorganic and Nuclear Chemistry Letters is a supplement to Journal of Inorganic and Nuclear Chemistry published by Pergamon Press since 1955. The Letters, in English or German, will provide for a rapid exchange of information. Communications included will be, of course, short and highly technical in nature.

Although Palaeogeography, Palaeoclimatology, Palaeoecology may eventually divide into separate specialized numbers for each of its three fields, it is presently an "international journal for the geo-sciences." Its scholarly, documented text is in English, French, or German and each article has, also, an English summary.

SCIENCE, Applied. Short news items with information on places to get help or materials are the specialties of Information Retrieval Letter. A larger publication, Systems and Communications, will cover the latest developments in communications and electronic technology. It will have sections on new products plus review articles and technical news notes. View; the Magazine of Closed-Circuit and Community Antenna $T V$ is designed "to reflect the importance of these fields in all facets of our commercial, industrial, recreational, and governmental lives." View includes some technical articles and much material about new products and new uses for old ones. Even one who knows little of the technical aspects of the subject can agree that "although we are most aware of the use of CCTV in its most dramatic aspects, as in the world shaking flight of the Gemini capsule, or in exploring the sea under the polar icecap, the use of closed circuit television cameras as everyday workhorses in banking, retail department stores, steel mills, schools, and the like, have made a far greater impact in today's world."

Acta Mechanica, although it will welcome papers on applied mathematics, is primarily concerned with all fields of theoretical or applied mechanics. Its articles are in English or German with summaries in both languages. Designed as an aid to engineers, Microwave Engineering will provide news, features, product and equipment reports, book reviews, and abstracts. Japan Chemical Quarterly is published in order to introduce to the world the economic and technical aspects of the chemical industry in Japan. The first issue includes articles on "Japan's Fertilizer Exports" and "Acrylic Fiber of Asahi Chemical."

Including in its first issue a number of articles on rice and coffee growing, Experimental Agriculture promises to publish "the results of experimental work in animal and crop husbandry, with an emphasis on research carried out in the warmer climates of the world." The new quarterly supersedes the highly regarded Empire Journal of Experimental Agriculture.

Designed for "physician-to-physician" communication, Medical Opinion \& Review will "isolate and explore aspects of the emerging cultural values within which the dual functions of physician and citizen must be discharged." The new monthly will have reviews, by physician reviewers, of new books on medicine and in ancillary subjects as well as information and discussions of postgraduate training programs and evaluation of new medical films and service materials. There will also be reports on developments in science, a music column, and a guide to art treasures.

Social ScIence. Articles in Voices; the Art and Science of Psychotherapy are not the scholarly, annotated type but seem to be, rather, short, amusing, somewhat random thoughts, quotes, or reviews. The quarterly, official publication of the American Academy of Psychotherapy, includes, also, much illustrative matter such as cartoons, portraits, etc.

An interesting and rather substantialseeming publication, Revista Latinoamericana de Sociología, will be issued from 
Buenos Aires by the Centro de Sociología Comparada of the Instituto Torcuato di Tella. In a desire to "differentiate the two main functions, that of the publication of scientific and scholarly output and that of serving as an organ of information and discussion for the professional concerns of sociologists as a social collectivity" the American Sociological Association has begun publication of The American Sociologist. The new periodical will serve as a channel for the publication of official reports and proceedings, news notes, obituaries, and other such material. It will include, also, articles on the profession itself. Research studies and other investigative reports will remain in the association's American Sociological Review and its other publications.

Urban Affairs Quarterly is issued by Sage Publications but sponsored by the City University of New York because, as the Chancellor of the university says in the first issue, "although many scholars and institutions are making important contributions to urban planning, transportation, housing, education, sociology, etc. the resources available have been limited, and the academic community has not made a commitment comparable to its activities in other areas. This is changing; the seriousness of urban problems commands attention from the scholarly community ... new legislative programs demonstrate dramatically increased governmental interest." The quarterly will provide a vehicle for the publication of results of the increased interest and, hopefully, of the increased activity. The editors, and the writers of articles in the first issue, are persons who are actually working in the field of urban affairs in universities or in the government.

\section{Periodicals}

Acta Mechanica. Springer-Verlag New York, Inc., 175 Fifth Ave., New York 10010. v. 1, no. 1, 1965. Frequency not given. Price not given. 65-9933.

African Commerce. P.O. Box 1442, Kampala, Uganda. v. 1, no. 1, Aug. 1965. Monthly. 40s. 65-9940.

African Forum. American Society of African Culture, 15 East 40th St., New York 10016. v. 1, no. 1, Summer 1965. Quarterly. \$4. 65-9921.

The American Sociologist. Executive Office,
American Sociological Association, Suite 215, 1755 Massachusetts Ave. N.W., Washington, D.C. 20036. v. 1, no. 1 , Nov. 1965. Quarterly. \$3. 65-9976.

American Studies. Editor, c/o Dept. of English, University of the Philippines, Diliman, Quezon City, Philippines. v. 1, no. 1, Apr. 1965. Semiannual. Price not given. SA65-9983.

Asian Outlook. Ku Cheng-kang, 1707 Chung-cheng Road, Taipei, Taiwan, Republic of China. v. 1, no. 1, Aug. 1965. Frequency not given. $\$ 2.50$ ( $\$ 5$ air mail). 65-9952.

-Astrofizika. Akademiia nauk Armianskoi SSR, Barekamutian 24, Erevan 19, Armenian SSR. v. 1, no. 1, Feb. 1965. 4 no. a year. 1 ruble. $65-9922$.

- British Corrosion Journal. British Joint Corrosion Group, 14 Belgrave Square, London S.W.1. v. 1, no. 1, July 1965. Bimonthly. $27 / 10 /-$ ( 9 issues, to end of 1966). 65-9969.

- Building Science. Pergamon Press, 122 East 55th St., New York 10022. v. 1, no. 1, Jan. 1965. Quarterly. \$30. 65-9941.

Business Economics. Ralph E. Burgess, Executive Secretary-Treasurer, National Association of Business Economists, P.O. Box 2804, Washington, D.C. 20013. v. 1, no. 1 , Summer 1965. 3 no. a year. $\$ 4$. 65-9977.

California Western Law Review. Managing Editor, California Western Law Review, 3902 Lomaland Dr., San Diego, Calif. 92106. v. 1, no. 1, Spring 1965. Annual. \$3. 65-9948.

- Carbohydrate Research; an International Journal. Elsevier Publishing Company, P.O. Box 211, Amsterdam, The Netherlands. v. 1, no. 1, July/Aug. 1965. Bimonthly. \$17.50, 65-9978.

Centro. Center for Latin American Studies, City College of the City University of New York, New York. no. 1, June 1965. Frequency not given. Price not given. 65-9894.

Columbia Journal of World Business. Pergamon Press, 122 East 55th St., New York 10022. v. 1, inaugural issue, Fall 1965. Quarterly. \$10. 65-9951.

Directory of Published Proceedings. InterDok, 6 Kenneth Rd., White Plains, N.Y. v. 1, no. 1, Sept. 1965. Monthly. $\$ 38$. 65-9931.

Discovery. Peabody Museum of Natural 
History, Yale University, New Haven, Conn. v. 1, no. 1, Fall 1965. Semiannual. Free to members of Peabody Museum Associates. 65-9974.

East European Science Abstracts. Translation and Technical Information Services, 32 Manaton Road, London S.E.15. v. 1, no. 1, Jan. 1965. Monthly. Price not given. 65-9926.

-European Polymer Journal, Pergamon Press, 122 East 55th St., New York 10022. v. 1, no. 1, Feb. 1965. Quarterly. $\$ 50.65-9925$.

Experimental Agriculture. Cambridge University Press, American Branch, 32 East 57 th St., New York 10022 . v. 1 , no. 1 , Jan. 1965. Quarterly. \$13.50. 65-9962.

Film Heritage. Film Heritage, Box 42, University of Dayton, Dayton, Ohio 45409. v. 1, no. 1, Fall 1965. Quarterly. \$2. 65-9973.

Forum for Modern Language Studies. Professor W. E. Rex, Dept. of French, University of California, Berkeley, Calif. v. 1, no. 1, Jan. 1965. Quarterly. $\$ 5$ (for direct order) $\$ 6$ (order through bookseller or agent). 65-9961.

The Hellenic American National Picture Magazine. 1810 Washington Blvd. Bldg., Detroit, Mich. 48024. v. 1, no. 1, Sept. 1965. Monthly. \$6. 65-9950.

Industrial Japan. Dentsu Advertising Limited, English Publications Dept., GinzaNishi, Chuo-Ku, Tokyo, Japan. no. 1, Oct. 1965. Quarterly. $\$ 10$ (seamail) $\$ 16$ (air mail). 65-9963.

Information Retrieval Letter. American Data Processing, Inc., 2200 Book Tower, Detroit, Mich. 48226. v. 1, no. 1, May 1965. Monthly. \$24. 65-9979.

Inorganic and Nuclear Chemistry Letters. Pergamon Press, 122 East 55th St., New York 10022. v. 1, no. 1, Sept. 1965. Monthly. \$50. 65-9959.

Japan Chemical Quarterly. Chemical Economy Research Institute, Takakubo Bldg., 28, 3-chome, Kanda Ogawa-machi, Chiyoda-ku, Tokyo, Japan. v. 1, no. 1, July 1965. Quarterly. \$5.50. 65-9966.

'Journal of Labelled Compounds. Presses Académiques Européennes, 98, Chaussée de Charleroi, Bruxelles 6, Belgium. v. 1, no. 1, Jan./Mar. 1965. Quarterly. \$25. 65-9984.

Journal of Purchasing. National Association of Purchasing Agents, Inc., 11 Park Place, New York 10007. v. 1, no. 1, May 1965. Quarterly. \$6. 65-9935.

-The Journal of Strain Analysis. Institution of Mechanical Engineers, 1 Birdcage Walk, Westminster, S.W.1, London. v. 1, no. 1, Oct. 1965. Quarterly. \&3/-/-. 65-9967.

Latin American Research Review. LARR Subscriptions, University of Texas Press, Austin, Texas 78712 . v. 1, no. 1, Fall 1965. 3 no. a year. \$8. 65-9960.

Lawyer's Medical Journal. Baker, Voorhis \& Co., Inc., Mount Kisco, New York. v. 1, no. 1, May 1965. Quarterly. \$25. 659936.

Liberian Law Journal. Faculty of the Louis Arthur Grimes School of Law, University of Liberia, Monrovia, Liberia, West Africa. v. 1, no. 1, June 1965. Semiannual. \$2 (per issue). 65-9919.

Lithopinion. Lithopinion, 113 University Place, New York 10003. v. 1, no. 1, Fall 1965. Quarterly. Free to qualified persons and institutions. 65-9965.

The Lugano Review. James Fitzsimmons, Via Maraini 17a, Lugano, Switzerland. v. 1 , no. $1,1965.6$ no. a year. $\$ 15$. 65-9927.

Medical Book Profiles. R. R. Bowker Co., 1180 Avenue of the Americas, New York 10036. v. 1, no. 1, Aug. 1965. Monthly. Price not given. 65-9954.

Medical Opinion \& Review. 1860 Broadway, New York 10023. v. 1, no. 1, Oct. 1965. Monthly. \$14. 65-9942.

Microwave Engineering. Ashbourne Publications Ltd., Ashbourne House, Alberon Gardens, London, N.W.11. v. 1, no. 1, June 1965. Bimonthly. \$9. 65-9964.

- Molecular Pharmacology. Academic Press Inc., 111 Fifth Ave., New York 10003. v. 1 , no. 1 , July 1965 . Bimonthly. \$11 (for 3 issues of 1965). 65-9928.

Mundus. Wissenschaftliche Verlagsgesellschaft m.b.H., Postfach 40, Stuttgart 1, Germany. v. 1, no. 1, 1965. Quarterly. \$20. 65-9980.

Nature and Resources. Natural Resources Research Division, Dept. of Advancement of Science, UNESCO, Place de Fontenoy Paris $7 \mathrm{e}$, France. v. 1, no. 1/2, June 1965. Quarterly. Price not given. 65-9958.

The Negro in Print. Negro Bibliographic 
and Research Center, Inc., 117 R. Street N.E. Washington, D.C. 20002. v. 1, no. 1, May 1965. Bimonthly. \$7.25. 659916.

-Neuroendocrinology. S. Karger AG, Arnold-Bocklin-Strasse 25, 4000 Basel, Switzerland. v. 1 , no. $1,1965 / 66$. Bimonthly. $\$ 15.50$. 65-9943.

Northwest Folklore. University of Oregon Publications, Friendly Hall, Eugene, Ore. v. 1, no. 1, Summer 1965. Semiannual. $\$ 2.50 .65-9944$.

Palaeogeography, Palaeoclimatology, Palaeocology. Elsevier Publishing Company, P.O. Box 211, Amsterdam, The Netherlands. v. 1 , no. 1 , Mar. 1965 . 4 no. a year. \$14. 65-9956.

Private Pilot. Gallant Publishing Company, 550A S. Citrus Ave., Covina, Calif. v. 1, no. 1 , Oct./Nov. 1965. Bimonthly. \$3.25. 65-9949.

Religious Studies. Cambridge University Press, American Branch, 32 East 57th St., New York 10022. v. 1, no. 1, Oct. 1965. Semiannual. \$9.50. 65-9981.

Revista Latinoamericana de Sociología. Administración, Revista Latinoamericana de Sociología, Virrey del Pino 3230, Buenos Aires, Argentina. v. 1, no. 1, Mar. 1965. 3 no. a year. \$5. 65-9972.

School Safety. National Safety Council, Editorial and Executive Office, 425 North Michigan Ave., Chicago 60611. v. 1, no. 1, Sept./Oct. 1965. 4 no. a year. $\$ 3.60$. 65-9945.

Sci-Tech Book Profiles. R. R. Bowker Co., 1180 Avenue of the Americas, New York 10036. v. 1, no. 1, Aug. 1965. Monthly. Price not given. 65-9955.

Science Books; a Quarterly Review. Science Books, American Association for the Advancement of Science, 1515 Massachusetts Ave. N.W., Washington, D.C. 20005. v. 1, no. 1, Apr. 1965. Quarterly. $\$ 4.50 .65-9914$.

Southern Education Report. Southern Education Reporting Service, P.O. Box 6156, Nashville, Tenn. 37212 . v. 1, no. 1, July/ Aug. 1965. Bimonthly. \$2. 65-9938.

Syn; International Contributions to the New Art. Agis Verlag, 757 Baden-Baden, Lichtentaler Allee 84. 1, 1965. 3 no. a year. DM 36-. 65-9971.

Systems and Communications. Systems Publications Ltd., Bugle House, 2la Noel St.,
London W.1. v. 1, no. 1, Sept. 1965. Monthly. \$11 (free to certain categories of subscriber). 65-9946.

Theatre Design \& Technology. 1117 C.L., 4200 5th Ave. Pittsburgh 15213. no. 1, May 1965. 4 no. a year. \$6. 65-9932.

Urban Affairs Quarterly. Sage Publications Inc., 150 Fifth Ave., New York 10011. v. 1, no. 1, Sept. 1965. Quarterly. \$12. 65-9957.

View; the Magazine of Closed-Circuit and Community Antenna TV. RT Publishing Co., 10 Poplar Road, Ridgefield, Conn. 06877. v. 1, no. 1, Aug. 1965. Bimonthly. \$6. 65-9970.

Vista. United Nations Association of the United States of America Inc., 345 East 46th St., New York 10017. v. 1, no. 1, July/Aug. 1965. Bimonthly. Price not given. 65-9924.

Voices; the Art and Science of Psychotherapy. Alexander Jasnow, Managing Editor, 14-11 Lucena Drive, Fair Lawn, N.J. 07410. v. 1, no. 1, Fall 1965. Quarterly. \$8. 65-9947.

Voyageur. Box 5226 Powderhorn Station, Minneapolis, Minn. 55407. v. 1, no. 1, 1965. Semiannual. $\$ 2$ (per issue). 659939.

Weekly Compilation of Presidental Documents. Superintendent of Documents, U.S. Government Printing Office, Washington, D.C. 20402. v. 1, no. 1, Aug. 2, 1965. Weekly. \$6. 65-9929.

\section{DOCTORAL PROGRAMS . . .}

(Continued from page 129)

grees granted and of library holdings and book expenditures strongly support the view that the two go hand in hand in universities distinguished for their doctoral programs. An institution outstanding for its graduate offerings is almost invariably equally notable for the strength of its library resources. It is perhaps equally obvious that a substantial number of institutions giving the doctorate lack the library resources to support advanced-level graduate study, and should either discontinue such offerings or undertake extensive development of their libraries. 